\title{
PENGEMBANGAN LEMBAR KERJA MAHASISWA BERBASIS HIGH ORDERTHINKING SKILLS PADA MATAKULIAH MATEMATIKA DI UNIVERSITAS TERBUKA
}

\author{
Tri Dyah Prastiti \\ Sri Tresnaningsih \\ Dina Thaib \\ Universitas Terbuka \\ e-mail: tridyahprastiti@ecampus.ut.ac.id
}

\begin{abstract}
Mathematical thinking is divided into lower-order thinking skills (LOTS) and higherorder thinking skills (HOTS). The LOTS is consisted of recall thinking and basic thinking, while HOTS required a more complex thinking abilities such as critical thinking and creative thinking. This research is aimed to develop a valid, effective, and practical HOTS-based worksheet for S1 PGSD students who took Mathematics course in Universitas Terbuka. The application of HOTS-based worksheet is expected to be able to improve students' learning motivation, as well as their ability in thinking critically and creatively in solving mathematical problems. The research is a developmental research, and the obtained data were analyzed descriptively. The subjects of this research were 72 students of S-1 PGSD program Universitas Terbuka Surabaya who took Mathematics (PDGK4108) course. The results showed that the developed HOTS-based worksheet fulfils the validity, practical, and effective criteria to improve students' learning motivation, which can be seen that $77 \%$ of students (56 students) felt encouraged and motivated to think critically and creatively, $72 \%$ of students (52 students) showed the ability to solve problem based questions. Furthermore, $78 \%$ of the students (41 students) achieved 75 out of 100 score or more. It can be concluded that the application of the developed HOTSbased worksheet is suitable in teaching Mathematics.
\end{abstract}

Keywords: HOTS-based worksheet, Mathematics, Students

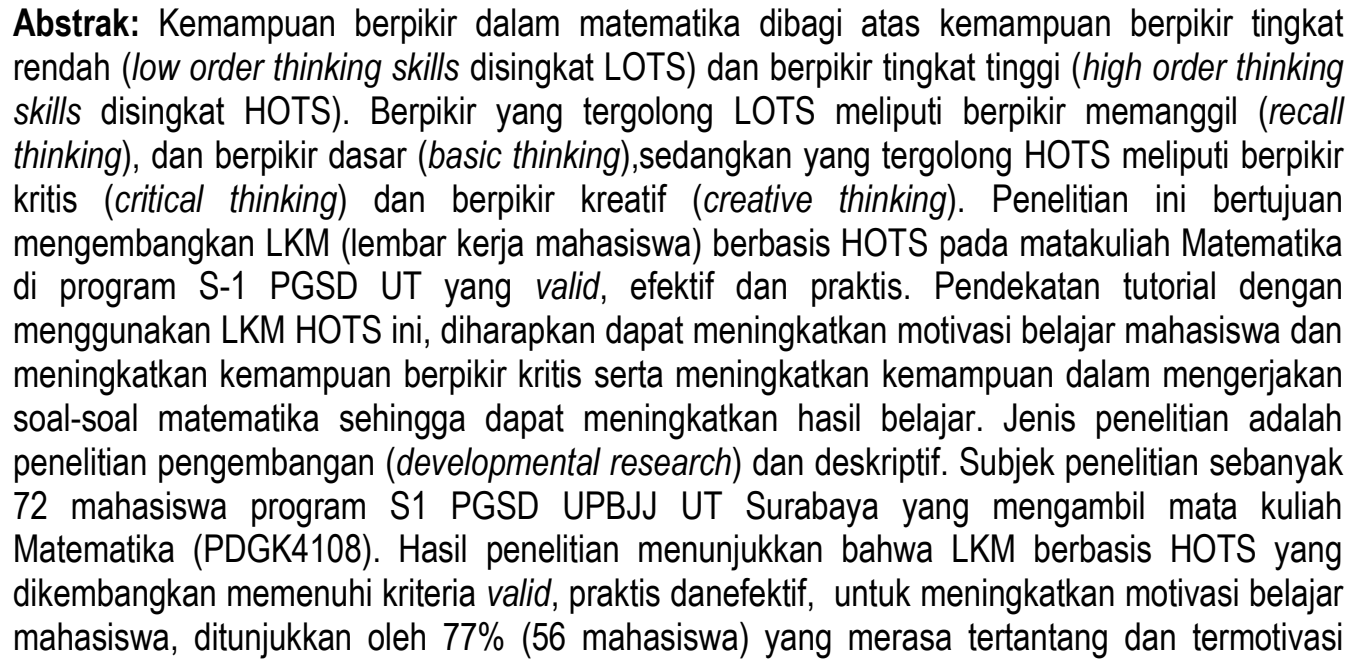


untuk berpikir tingkat tinggi (kritis, dan kreatif), 72\% (52 mahasiswa) mampu menyelesaikan soal-soal yang bersifat pemecahan masalah, dan dari mahasiswa yang mampu tersebut ada sebanyak $78 \%$ (41 mahasiswa) mendapat nilai lebih dari atau sama 75 dari skor maksimal 100. Penelitian ini menyimpulkan bahwa LKM bebasis HOTS yang dikembangkan cocok untuk diaplikasikan dalam pengajaran matematika.

Kata kunci: Lembar Kerja HOTS, Matematika, Mahasiswa

\section{PENDAHULUAN}

Kemampuan berpikir dalam matematika dibagi atas berpikir memanggil (recall thinking), berpikir dasar (basic thinking), berpikir kritis (critical thinking) dan berpikir kreatif (creative thinking). Berpikir memanggil adalah berpikir yang diarahkan untuk memanggil informasi yang telah diingat atau dipelajari sebelumnya oleh mahasiswa. Contoh soal dengan berpikir ini adalah "sebutkan bentuk umum dari persamaan lingkaran?". Mahasiswa mampu menjawab soal ini dengan segera tanpa perlu melakukan aktivitas kognitif tertentu jika pengetahuan mengenai bentuk umum tersebut ada dalam pikiran mahasiswa. Berpikir dasar adalah berpikir yang diarahkan untuk menerapkan suatu aturan atau rumus tertentu secara langsung dalam menjawab soal tertentu. Contohnya "Tentukan jari-jari dari lingkaran dengan persamaan $(x-2)^{2}+$ $(y-3)^{2}=9$ ". Jika mahasiswa memiliki pengetahuan bentuk umum persamaan lingkaran $(x-a)^{2}+(y-b)^{2}=9$ dan mengetaui bahwa $(a, b)$ adalah titik pusat dari lingkaran tersebut, maka mahasiswa dapat menjawabnya". Soal ini lebih dari soal dengan berpikir memanggil. Akan tetapi, kedua kemampuan ini masih tergolong kemampuan berpikir tingkat rendah (low order thinking skills disingkat LOTS) (Krulik, Rudnick, \& Milou, 2003).

Kemampuan berpikir kritis dan kreatif berbeda dengan LOTS. Kemampuan berpikir kritis dan kreatif tergolong kemampuan berpikir tingkat tinggi (high order thinking skills disingkat HOTS). Berpikir kritis adalah berpikir yang diarahkan untuk memecahkan masalah-masalah matematika (King, Goodson, \& Rohani, 2016). Masalah matematika dalam HOTS berbeda dengan soal yang bersifat LOTS. Soal LOTS sering disebut dengan soal rutin sedangkan masalah matematika dalam HOTS bukanlah soal rutin tetapi soal matematika dimana cara untuk menyelesaikannya tidak segera dapat dilihat mahasiswa (Polya, 1973; Posamenteir \& Krulik, 2009). Contoh masalah dalam HOTS: "Tentukan persamaan garis yang tegak lurus dengan garis yang melalui titik $(0,1)$ dan $(3,0)$, dan garis tersebut membagi lingkaran $x^{2}+y^{2}-4 x+6 y+9=0$ sama besar". Masalah ini tidak dapat diselesaikan hanya dengan menerapkan rumusrumus tertentu. Mahasiswa perlu membentuk gambar mental, dan mengelaborasi konsep-konsep yang relevan, pengalaman sebelumnya dan strategi/ pendekatan pemecahan masalah untuk mengembangkan rencana pemecahan masalah. Dengan demikian, mahasiswa tidak segera dapat melihat cara penyelesaian suatu masalah.

Berpikir kreatif adalah berpikir yang diarahkan untuk menentukan jawaban atau cara penyelesaian berbeda dari suatu masalah matematika. Mahasiswa dapat 
mencapai tingkat ini setelah mampu menyelesaikan suatu masalah dan berpikir lebih lanjut untuk menentukan jawaban atau cara berbeda dari masalah tersebut. Dengan kata lain, berpikir kreatif dapat dicapai setelah mahasiswa mencapai berpikir kritis. Contoh soal dengan berpikir ini adalah "suatu lingkaran $x^{2}+y^{2}-2 a x-8 y+$ $16=0$ menyinggung garis $x=6$. Tentukan nilai $a$. Adakah cara lain untuk menentukan nilai $a$ ? Jika ada, selesaikan dengan cara tersebut".

Mahasiswa diharapkan dapat memiliki HOTS yang diukur berdasarkan kemampuan berpikir kritis dan kreatifnya. Kemampuan tersebut berkaitan dengan kemampuan pemecahan masalah matematika sesuai definisi dari berpikir kritis dan kreatif. Hasil penelitian menunjukkan bahwa mahasiswa program studi pendidikan matematika angkatan 2016 di universitas di Kalimantan Tengah sebesar 9,18 (skala 024). Jika dikonversi ke skala 100 , nilainya menjadi 38,25. Kemampuan mahasiswa tersebut dapat digolongkan menjadi pemecah masalah yang baik (good problem solver), pemecah masalah yang rutin (routine problem solver) atau pemecah masalah yang kurang berpengalaman (naive problem solver). Hasil penelitian tersebut juga menunjukkan bahwa mahasiswa yang tergolong pemecah masalah yang kurang berpengalaman sebanyak $8,5 \%$, pemecah masalah yang rutin sebanyak $91,5 \%$, dan tidak ada mahasiswa dengan pemecah masalah yang baik (Mairing, 2016).

Lebih lanjut, HOTS juga diukur berdasarkan tingkat kemampuan berpikir kreatif mahasiswa. Berpikir ini merupakan kemampuan tertinggi dalam matematika. Tingkat kemampuan berpikir kreatif yang disingkat dengan TKBK terdiri dari 5 yaitu sangat kreatif (TKBK 4), kreatif (TKBK 3), cukup kreatif (TKBK 2), kurang kreatif (TKBK 1) atau tidak kreatif (TKBK 0). Ada tiga indikator yang menentukan mahamahasiswa masuk dalam tingkat tertentu yaitu kefasihan, fleksibilitas dan kebaruan. Mahasiswa dikatakan memenuhi indikator kefasihan jika ia mampu atau fasih (lancar) dalam menemukan jawaban dari masalah-masalah matematika. Mahasiswa dikatakan memenuhi indikator fleksibilitas jika ia mampu menemukan cara lain (fleksibel) dalam menyelesaikan suatu masalah. Mahasiswa dikatakan memenuhi indikator kebaruan jika cara yang digunakan dalam menyelesaikan masalah tidak biasa dibuat mahasiswa pada umumnya (Siswono, 2008).

Dosen seharusnya menerapkan tutorial yang dapat membantu mahasiswamahasiswa UT (Universitas Terbuka) mengembangkan HOTS (kemampuan berpikir kritis dan kreatif). Penerapan tersebut harus mempertimbangkan sistem belajar di UT, dan karakteristik dari mahasiswa. UT menerapkan Sistem Belajar Jarak Jauh (SBJJ) yang menuntut mahasiswa UT belajar secara mandiri. Dalam belajar mandiri mahasiswa dituntut memiliki prakarsa atau inisiatif sendiri dalam mempelajari bahan ajar, mengerjakan tugas-tugas, memantapkan keterampilan, dan menerapkan pengalaman belajarnya di lapangan atau pekerjaan. Belajar mandiri dalam banyak hal ditentukan oleh kemampuan mahasiswa dalam mengatur waktu dan menerapkan strategi belajar efektif. Dengan demikian, mahasiswa harus memiliki disiplin diri, inisiatif, dan motivasi yang kuat untuk belajar. Belajar mandiri dapat dilakukan secara perorangan maupun kelompok dengan menggunakan bahan ajar cetak atau non-cetak 
sebagai sumber belajar. Untuk membantu mahasiswa belajar, UT menyediakan layanan bantuan belajar.

Sistem belajar mandiri membuat mahasiswa UT memiliki karakteristik khusus. Pertama, mahasiswa UT berpikir mandiri yaitu keberhasilan belajar di UT ditentukan oleh dirinya sendiri karena itu mahasiswa UT harus membangun potensi diri dengan caranya sendiri. Kedua, mahasiswa UT gigih, kerja keras, dan tidak mudah putus asa yaitu mahasiswa UT harus mempunyai rencana belajar yang terprogram, tidak ada waktu yang tersia-sia, setiap waktu, setiap hari harus ada target yang dilaksanakan (Universitas Terbuka, 2016).

Salah satu matakuliah di pogram studi pendidikan guru SD yang menuntut mahasiswa belajar dengan sistem belajar demikian adalah matakuliah Matematika. Materi-materi dalam matakuliah ini adalah logika, penalaran dan sistem matematika, persamaan dan pertidaksamaan linear, persamaan dan pertidaksamaan linear, himpunan, relasi dan fungsi, peluang, aritmetika sosial, pengantar Statistika I dan II, pemecahan masalah, transormasi, kekongruenan dan kesebangunan. Materi-materi tersebut menuntut mahasiswa memiliki HOTS untuk dapat memahaminya secara bermakna. Sebaliknya, mahasiswa yang mendasarkan pemahaman materi-materi tersebut pada LOT skills akan menganggap bahwa matakuliah Matematika sulit. Pendapat yang demikian akan membuat mahasiswa tidak termotivasi dan akhirnya memperoleh hasil belajar yang kurang memuaskan.

Saat ini UT telah memiliki Buku Materi Pokok matakuliah Matematika (PDGK 4108) sebagai bahan belajar utama bagi mahasiswa. Akan tetapi, buku tersebut perlu dilengkapi dengan lembar kerja untuk lebih mengaktifkan kegiatan tutorial sehingga mahasiswa secara aktif mengembangkan HOTS di kegiatan tutorial yang jumlahnya terbatas dalam satu semester sebanyak 8 kali. Terbatasnya kegiatan belajar dalam tutorial tatap muka membuat mahasiswa harus lebih mengandalkan belajar secara mandiri. Ketersediaan lembar kerja diharapkan dapat meningkatkan motivasi mahasiswa untuk belajar secara mandiri menggunakan LK, dan terlihat pengaruhnya pada hasil belajar yang meningkat.

Berdasarkan permasalahan di atas, penelitian ini dilakukan dengan tujuan untuk mengembangkan LKM (lembar kerja mahasiswa) berbasis high order thinking skills disingkat HOTS (kemampuan berpikir tingkat tinggi) pada matakuliah Matematika. Lembar kerja tersebut berisi pertanyaan pertanyaan yang membantu mahasiswa mengkonstruksi pemahamannya terhadap materi materi dalam matakuliah matematika.. Lebih lanjut LKM ini juga berisi masalah masalah matematika yang membantu mahasiswa mengembangkan HOTS. Mahasiswa menggunakan lembar kerja ini sebagai tempat untuk bekerja dan menuliskan penyelesaian dari setiap pertanyaan atau masalah. Hasil penelitian menunjukkan bahwa penggunaan lembar kerja ini dapat mendorong mahasiswa untuk memiliki pengetahuan bermakna, termotivasi untuk belajar, dan meningkatkan hasil belajar mahasiswa (Mairing \& Lorida, 2018). 


\section{METODE PENELITIAN}

Tujuan penelitian ini adalah mengembangkan LKM HOTS yang yang valid, efektif, dan praktis, yang memenuhi kriteria sebagai berikut.

1. Lembar kerja mahasiswa dikatakan valid jika

a. semua ahli menyatakan bahwa materi-materi dalam LKM sesuai dengan konsep-konsep matematika, dan

b. semua ahli menyatakan bahwa sintaks pembelajaran dengan LKM sesuai dengan teori-teori HOTS.

Ada tiga ahli yang digunakan dalam penelitian ini yaitu satu praktisi matematika (tutor UT pada matakuliah Matematika, dan dua doktor pendidikan matematika yang ahli di bidang HOTS).

2. Lembar kerja mahasiswa dikatakan efektif jika

a. Lebih dari $70 \%$ mahasiswa yang memperoleh nilai lebih dari atau sama dengan 75 , dan

b. ada $75 \%$ mahasiswa merespons positif LKM HOTS.

3. Lembar kerja mahasiswa dikatakan praktis jika setidaknya $80 \%$ aktivitas dalam setiap SAT (Satuan Aktivitas Tutorial) yang menggunakan LKM HOTS dapat dilaksanakan oleh tutor.

\section{Model Pengembangan}

LKM dikembangkan menggunakan tahap-tahap model pengembangan produk prosedural (Karyadi \& Tantra, 2007). Secara rinci prosedur pengembangan media tersebut dapat dilihat pada Gambar 1.

A. Identifikasi kebutuhan tutorial

B. Merumuskan kompetensi umum dan khusus di setiap tutorial

\begin{tabular}{|c|c|c|c|c|}
\hline & & \\
\hline PEREN- & STUDI \\
CANAAN & $\begin{array}{c}\text { EKSPLORA } \\
\text { SI }\end{array}$ & $\begin{array}{c}\text { PENGEMBAN } \\
\text { GAN PRODUK } \\
\text { AWAL }\end{array}$ & $\begin{array}{c}\text { VALIDASI } \\
\text { PRODUK }\end{array}$ & UJI \\
LAPANGAN
\end{tabular}

A. Analisis materi materi matakuliah Matematika

B. Analisis karakteristik mahasiswa
1. Draft 1 LKM HOTS

2. Tutorial kits (RAT, SAT dan RE

3. Lembar pengamatan Uji lapangan di aktivitas mahasiswa Pokjar Surabaya.

4. Angket mahasiswa Hasilnya LKM

5. Lembar Penilaian Ahli

\section{HOTS}

LKM

HOTS yang valid, efektif dan praktis

Gambar 1. Prosedur pengembangan LKM HOTS 
Secara umum, teknik analisis data dalam penelitian ini adalah mengorganisasi data, mereduksi data, menyajikan data dalam bentuk tabel atau grafik, melakukan analisis deskriptif pada data kuantitatif, dan mendeskripsikan data kuantitatif (Karyadi \& Tantra, 2007).

Lembar Kerja berisi pertanyaan-pertanyaan yang membantu mahasiswa mengkonstruksi pemahamannya terhadap materi dalam matakuliah Matematika. Materi-materi tersebut meliputi: Logika, persamaan kuadrat, fungsi, peluang, statistika, pemecahan masalah dan transformasi. Lembar kerja juga berisi pertanyaan pertanyaan untuk setiap kemampuan berpikir tingkat tinggi, yaitu berpikir logis, kritis, dan kreatif. Mahasiswa berdiskusi dalam kelompok untuk menyelesaikan pertanyaan atau masalah dalam lembar kerja. Penyelesaiannya ditulis pada tempat yang disediakan dalam lembar kerja. Contoh pertanyaan yang membantu mahasiswa untuk mengkonstruksi pemahaman mengenai makna "FUNGSI" adalah sebagai berikut.

\section{MAKNA FUNGSI}

Fungsi adalah relasi khusus. Relasi dari himpunan A ke B dalam matematika didefinisikan sebagai suatu aturan yang mengaitkan anggota anggota himpunan $A$ ke B. Kekhususan dari fungsi dapat kita temukan setelah membandingkan sifat-sifat yang dimiliki oleh fungsi tetapi tidak dimiliki oleh bukan fungsi.

\begin{tabular}{llll}
\hline No Fungsi & Bukan Fungsi & $\begin{array}{l}\text { Sifat yang dimiliki fungsi, te } \\
\text { tidak dimiliki oleh bukan fun }\end{array}$ \\
\hline$(1)$ & $(3)$ & $\begin{array}{l}\text { (amati anggota-anggota } \\
\text { himpunan } A \text { yang memiliki } \\
\text { pasangan di himpunan } B)\end{array}$ \\
\hline
\end{tabular}




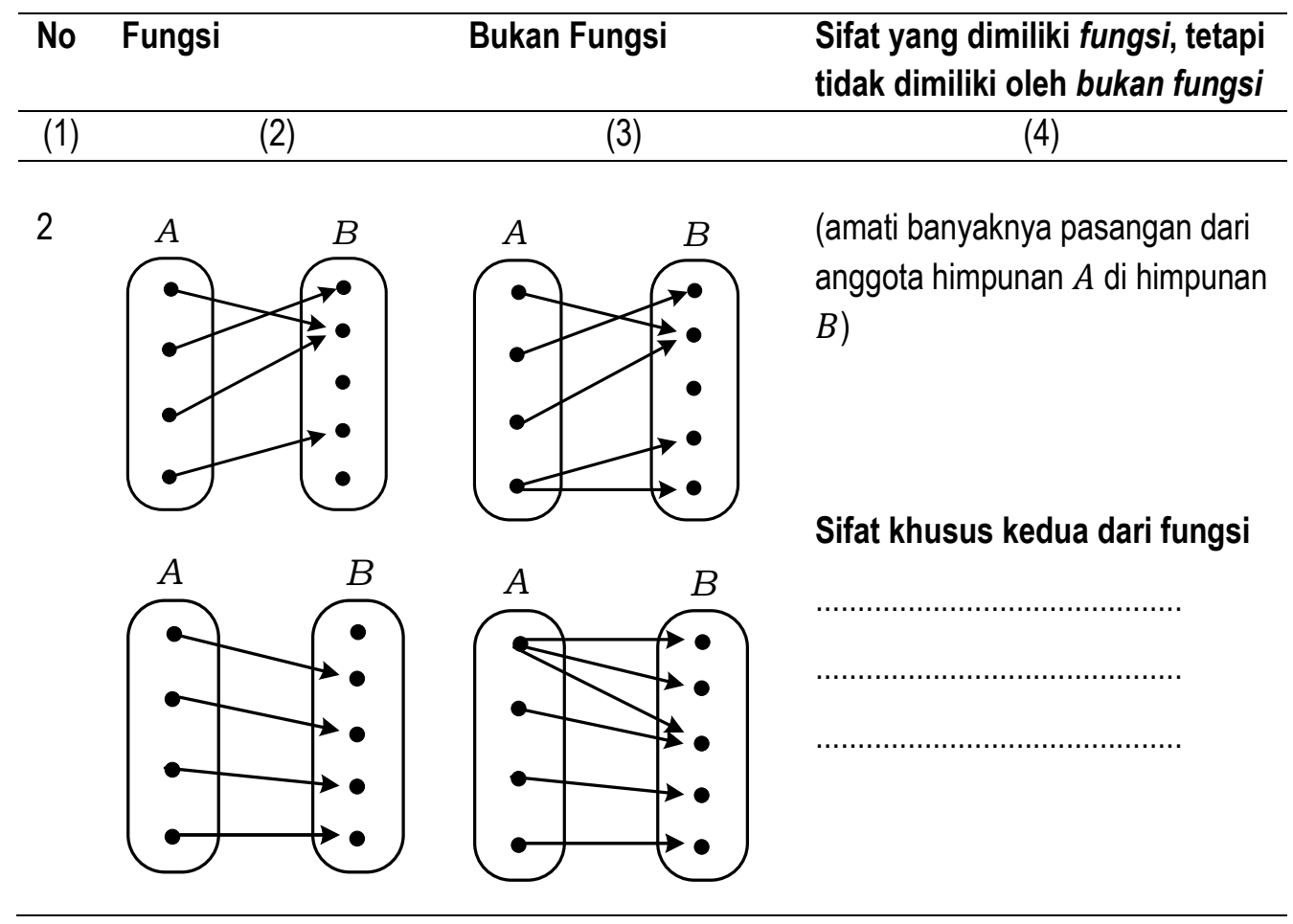

(logical thinking)

Berdasarkan sifat pertama dan kedua, makna dari fungsi adalah.

Fungsi adalah relasi khusus dimana

Contoh masalah matematika materi yang sama adalah:

\section{Masalah 3.2 .}

a. Misalkan $g(x)=2 x+5$ dan $g \circ f(x)=3 x^{2}+7$. Tentukan $f(0)$. Jelaskan jawabanmu.

b. Adakah cara lain untuk menjawab pertanyaan (a)? Jika ada, jelaskan jawabanmu.

Jawab:

a.

b. 
Subjek penelitian sebanyak 72 mahasiswa program S1 PGSD UPBJJ UT Surabaya yang mengambil mata kuliah Matematika (PDGK4108). Berdasarkan hasil yang diperoleh peneliti melakukan analisis deskriptif, dengan membandingkan data yang diperoleh dengan kriteria valid, praktis dan efektif yang telah ditentukan sebelumnya. Penjabaran analisis tersebut dapat dilihat pada Tabel 1.

Tabel 1. Data-data Penelitian Beserta Teknik Analisisnya

\begin{tabular}{llll}
\hline Kriteria & $\begin{array}{l}\text { Data yang } \\
\text { Dibutuhkan }\end{array}$ & $\begin{array}{l}\text { Instrumen } \\
\text { Pengumpul } \\
\text { Data }\end{array}$ & Teknik Analisis Data \\
\hline
\end{tabular}

\section{Kevalidan}

a. semua ahli menyatakan bahwa materi-materi dalam LKM sesuai dengan konsepkonsep matematika.

b. semua ahli menyatakan bahwa sintaks pembelajaran dengan LKM sesuai dengan teori-teori HOTS.

\section{Keefektifan}

a. Lebih dari $70 \%$ mahasiswa yang memperoleh nilai lebih dari atau sama dengan 75

b. ada $75 \%$ mahasiswa merespons positif LKM HOTS

\section{Kepraktisan}

Setidaknya 80\% aktivitas dalam setiap SAT (Satuan Aktivitas Tutorial) yang menggunakan LKM HOTS dapat dilaksanakan oleh tutor
Data penilaian Lembar ahli:

$1=S T S, 2=T S$,

$3=S$, dan

$4=S S$

Nilai

Masalah

Matematika

Data angket Angket $1=S T S, 2=T S$, mahasiswa $3=S$, dan $4=S S$
1. Data disajikan dalam bentuk tabel.

2. Data dibandingkan dengan Kriteria kevalidan
1. Data disajikan dalam bentuk tabel, grafik, rata-rata atau persentase.

2. Penarikan kesimpulan dengan membandingkan data dengan indikator
Data hasil Lembar pengamatan Pengamatan oleh observer: 0 = tidak dilaksanakan 1 = dilaksanakan
1. Data disajikan dalam bentuk tabel, grafik, rata-rata atau persentase.
2 Penarikan kesimpulan dengan membandingkan data dengan indikator




\section{HASIL DAN PEMBAHASAN \\ Hasil}

Pada tahap perencanaan, Tim peneliti mengidentifikasi kebutuhan tutorial yaitu mahasiswa-mahasiswa UT memiliki kemampuan berpikir tinggi yang dibutukan di jaman industri 4.0. Tim juga merumuskan kompetensi umum dan khusus di setiap tutorial. Kompetensi tersebut dituangkan dalam RAT (Rancangan Aktivitas Tutorial), dan SAT (Satuan Aktivitas Tutorial).

Pada tahap studi eksplorasi, Tim menganalisis materi-materi dalam matematika beserta karakteristiknya. Materi-materi dalam tutorial 1 s.d 8 secara berturut-turut adalah logika, persamaan kuadrat, fungsi, peluang, statistika, pemecahan masalah, transformasi, dan kekongruenan dan kesebangunan. Tim juga menganalisis karakteristik mahasiswa yaitu kemampuan awal dari mahasiswa, dan keaktifan mahasiswa secara umum dalam kegiatan tutorial.

Pada tahap pengembangan produk awal, Tim mengembangkan Draf 1 LKM HOTS, tutorial kit (RAT, SAT, Rancangan Evaluasi), dan instrumen penelitian. Instrumen tersebut adalah lembar pengamatan, angket mahasiswa dan lembar penilaian ahli. Metode yang digunakan dalam SAT didasarkan pada karakteristik materi, karakteristik mahasiswa, dan teori-teori dan hasil penelitian mengenai peningkatan HOTS. Metode tersebut adalah pembelajaran penemuan yang dipadukan dengan pembelajaran berbasis masalah.

Pada tahap validasi produk, Draf 1 LKM HOTS dinilai oleh 3 ahli menggunakan lembar penilaian ahli. Hasilnya menunjukkan bahwa (a) 3 ahli menyatakan bahwa materi-materi dalam LKM HOTS sesuai dengan konsep-konsep matematika, (b) 3 ahli menyatakan bahwa sintaks pembelajaran dengan LKM HOTS sesuai dengan teori-teori kemampuan berpikir tingkat tinggi, dan (c) LKM HOTS layak digunakan pada tutorial mata kuliah Matematika. Tim juga memperbaiki Draf 1 LKM HOTS berdasarkan saransaran dari ketiga ahli menjadi Draf 2 LKM HOTS. Dengan demikian, LKM HOTS telah memenuhi kriteria valid.

Pada tahap uji lapangan awal, Tim mengimplementasikan LKM HOTS pada mahasiswa-mahasiswa UPBBJ UT Pokjar Surabaya yang mengambil mata kuliah Matematika. Pada tahap awal penerapan, tutor memberikan apersepsi dan memotivasi mahasiswa untuk menyelesaikan pertanyaan-pertanyaan dalam LKM. Tutor juga memberikan penjelasan mengenai pentingnya HOTS dan bagaimana mengembangkannya. Pada tahap inti, mahasiswa berdiskusi dalam kelompok heterogen untuk menjawab pertanyaan-pertanyaan dalam LKM. Tutor membimbing mahasiswamahasiswa di setiap kelompok. Pertanyaan-pertanyaan dalam LKM digolongkan menjadi kategori logical, critical, creative, metacognitive, dan reflective thinking. Selanjutnya, setiap kelompok mempresentasikan hasil diskusinya di depan kelas. Tutor mendorong terjadinya diskusi kelas yang dapat membantu mahasiswa-mahasiswa untuk mengembangkan HOTS.

Pada waktu implementasi, tutor diamati oleh 3 orang pengamat. Dua pengamat mencatat tingkat keaktifan mahasiswa di setiap tutorial, sedangkan satu pengamat mengamati aktivitas tutor. Hasil pengamatan aktivitas tutorial menunjukkan bahwa rata- 
rata aktivitas dalam SAT yang dapat dilaksanakan tutor pada tutorial 1 s.d 8 secara berturut-turut sebesar $81,2 \%, 85,7 \%, 85,1 \%, 87,1 \%, 82,7 \%, 91,3 \%, 100 \%$, dan $98,6 \%$. Tampak bahwa lebih dari $80 \%$ aktivitas pada SAT dapat dilakukan oleh tutor di setiap pertemua. Rata-rata dari persentasi tersebut sebear 90\%. Dengan demikian LKM HOTS telah memenuhi kriteria kepraktisan.

Hasil pengamatan terhadap aktivitas mahasiswa menunjukkan bahwa persentase mahasiswa yang aktif dalam kegiatan tutorial pada tutorial $1 \mathrm{~s} . d 8$ secara berturut-turut sebesar $56,2 \%, 56,7 \%, 59,9 \%, 67,0 \%, 66,7 \%, 72,8 \%, 76,2 \%$, dan $75,8 \%$. Mahasiswa dikatakan aktif di suatu tutorial jika mahasiswa tersebut setidaknya 1 kali bertanya, menjawab pertanyaan, mencari jawaban, atau menulis jawaban. Dengan demikian, tutorial yang menggunakan LKM HOTS dapat meningkatkan keakftifan mahasiswa dalam kegiatan tutorial. Pada setiap akhir tutorial, mahasiswa menyelesaikan kuis individual. Rata-rata nilai kuis individual di tutorial 1 s.d 8 ditunjukkan Gambar 2. Rata-rata nilai kuis individual secara keseluruhan sebesar 74,0. Dengan demikian, hasil penelitian menunjukkan 7 dari 8 tutorial dimana rata-rata nilai kuisnya $\geq 75$. Secara khusus, pada kuis individual ke-8, ada 72 mahasiswa yang memperoleh nilai $\geq 75$ pada soal-soal yang bersifat pemecahan masalah. Hal serupa ditunjukkan oleh ratarata nilai tugas 1,2 dan 3 secara berturut-turut sebesar 78,$4 ; 80,7$ dan 81,1. Rataratanya secara keseluruhan sebesar 80,1 seperti terlihat pada Gambar 2.

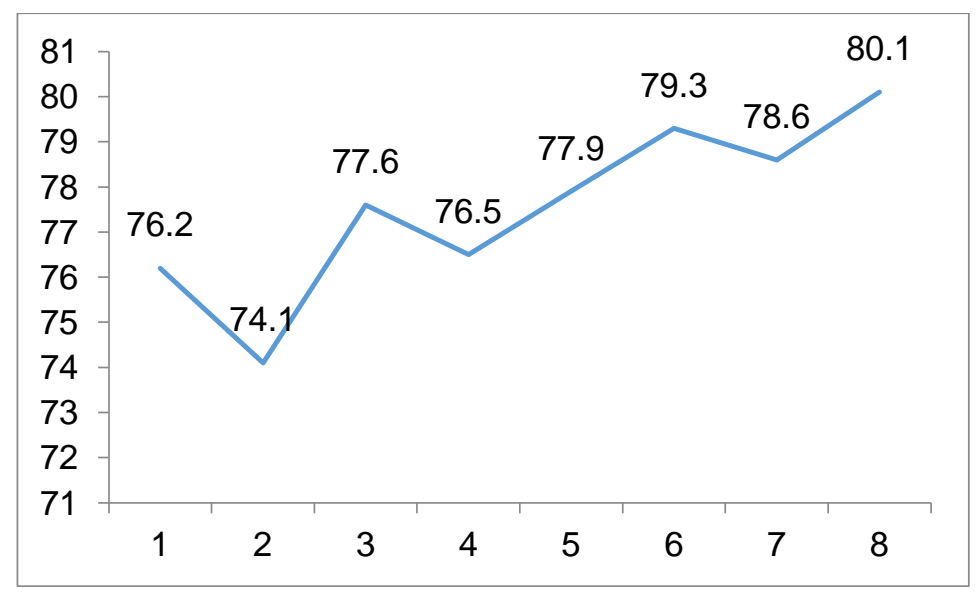

Gambar 2. Rata-rata kuis individual per tutorial

Hal yang sama ditunjukkandari hasil belajar mahasiswa dalam menyelesaikan soal-soal yang bersifat masalah matematika. Rata-rata hasil belajar tersebut adalah 77,8 dimana mahasiswa yang memperoleh nilai $\geq 75$ sebanyak $78 \%$. Dengan demikian, LKM HOTS telah memenuhi kriteria efektif bagian (a).

Pada pertemuan 7, Tim membagikan angket kepada semua mahasiswa. Hasil angket menunjukkan bahwa $77 \%$ mahasiswa merasa tertantang dan termotivasi untuk berpikir tingkat tinggi, 80,1\% mahasiswa dapat memahami materi lebih baik dengan LKM HOTS, 78,2\% mahasiswa mengharapkan mata kuliah lainnya yang berkaitan 
dengan matematika menggunakan LKM dan berdiskusi seperti pada mata kuliah Matematika. Dengan kata lain, ada 75\% mahasiswa merespons positif terhadap LKM HOTS dan metode belajar yang digunakan dalam mata kuliah Matematika. Jadi, LKM HOTS telah memenuhi kriteria efektif bagian (b).

Hasil-hasil penerapan mulai dari tutorial $1 \mathrm{~s} . \mathrm{d} 8$ digunakan tim untuk melihat kekurangan-kekurangan pada LKM HOTS atau pada cara penggunaannya. Tim juga me-review kekurangan pada aktivitas-aktivitas yang dilakukan oleh tutor atau mahasiswa. Hasil refleksi digunakan tim untuk memperbaiki Draf 2 LKM HOTS menjadi LKM berbasis HOTS.

\section{Pembahasan}

Mahasiswa-mahasiswa dalam kelompok dapat menjawab pertanyaan- pertanyaan dalam LKM berbasis HOTS. Ini berarti bahwa mahasiswa secara berkelompok mampu menunjukkan berpikir logis, kritis dan kreatif. Sebagai contoh, mahasiswa dapat menarik kesimpulan secara logis dari contoh-contoh dalam LKM. Mahasiswamahasiswa menunjukkan kemampuan menemukan dan menarik kesimpulan mengenai definisi dari fungsi.

Hasil-hasil penelitian ini sejalan dengan penelitian-penelitian relevan yang menyatakan bahwa pembelajaran dimana pebelajar diberikan kesempatan untuk berlatih menyelesaikan masalah-masalah matematika dapat mengembangkan kemampuan berpikir tingkat tinggi (Dewi \& Masrukan, 2018; Ho \& Hedberg, 2005; Suwarma, 2009). Selain itu, kemampuan berpikir tingkat tinggi juga dipengaruhi oleh pemahaman bermakna dari mahasiswa (Mairing, 2018; Polya, 1981). Hasil-hasil penelitian menunjukkan bahwa pembelajaran penemuan dapat membantu pebelajar mengonstruksi pemahaman secara bermakna (Fauziah, 2010; Prastiti \& Mairing, 2011).

Salah satu faktor lainnya yang mempengaruhi kemampuan berpikir tingkat tinggi adalah pengalaman pebelajar dalam menyelesaikan masalah-masalah (Mairing, Budayasa, \& Juniati, 2011). Tutor perlu membimbing mahasiswa di setiap tahap pemecah masalah pada waktu diskusi kelompok maupun diskusi kelas. Tahap-tahap tersebut adalah memahami masalah, mengembangkan rencana, melaksanakan rencana dan memeriksa kembali (Polya, 1973). Aktivitas tersebut telah dilakukan oleh tutor dalam penelitian ini dan berdampak pada peningkatan kemampuan berpikir tinggi dari mahasiswa-mahasiswa UT.

\section{KESIMPULAN DAN SARAN}

Tujuan penelitian ini adalah mengembangkan LKM (lembar kerja mahasiswa) berbasis high order thinking skills disingkat HOTS (kemampuan berpikir tingkat tinggi) pada matakuliah Matematika di program S-1 PGSD UT yang valid, efektif dan praktis. Hasil penelitian menunjukkan bahwa LKM berbasis HOTS yang telah dikembangkan telah memenuhi kriteria valid, praktis dan efektif. Hasil angket menunjukkan bahwa $77 \%$ mahasiswa merasa tertantang dan termotivasi untuk berpikir tingkat tinggi. Hasil kuis individual menunjukkan $72 \%$ mahasiswa mampu menyelesaikan soal-soal yang bersifat pemecahan masalah. Hasil belajar mahasiswa yang ditunjukkan dengan menyelesaikan 
soal yang bersifat pemecahan masalah terjadi peningkatan kemampuan yaitu $78 \%$ mendapat nilai sama atau diatas 75 (skor maksimal 100).

LKM berbasis HOTS yang dikembangkan dalam penelitian ini perlu dilanjutkan dengan menerapkannya lebih luas. Hasil penerapan yang lebih luas akan membuat LKM ini lebih baik dalam meningkatkan kemampuan berpikir tingkat tinggi dari mahasiswa-mahasiswa UT. Selain itu, hasil identifkasi karakteristik materi-materi matakuliah Matematika menunjukkan adanya kemungkinan penggunaan komputer di beberapa materi. Penggunaan komputer dalam tutorial dapat membantu mahasiswa mengeksplorasi konsep-konsep secara dinamis dan menarik. Bukan hanya itu, penggunaan komputer dapat membantu mahasiswa bersaing di era industri 4.0.

\section{REFERENSI}

Dewi, N. R., \& Masrukan, M. (2018). Peningkatan kemampuan berpikir kreatif mahasiswa program magister. PRISMA, Prosiding Seminar Nasional Matematika, 1 (pp. 539-546). Semarang: Unnes.

Fauziah, A. (2010). Peningkatan kemampuan pemahaman dan pemecahan masalah matematik siswa SMP melalui strategi REACT. Forum Kependidikan, 30 (1), 112.

Ho, K. F., \& Hedberg, J. G. (2005). Teachers' pedagogies and their impact on students' mathematical problem solving. Journal of Mathematical Behaviour, 24, 238252.

Karyadi, B., \& Tantra, D. K. (2007). Pengembangan inovasi pembelajaran. (B. Karyadi, \& D. K. Tantra, Eds.) Jakarta, Indonesia: Direktorat Ketenagaan Dirjen Dikti.

King, F. J., Goodson, L., \& Rohani, F. (2016). Higher order thinking skills. Centre for Advancement of Learning and Assessment.

Krulik, S., Rudnick, J., \& Milou, E. (2003). Teaching mathematics in middle schools. A practical guide. Boston, MA: Pearson Education Inc.

Mairing, J. P. (2016). Kemampuan mahasiswa pendidikan matematika dalam memecahkan masalah. EDUMATICA, VI (2), 11-30.

Mairing, J. P. (2018). Pemecahan masalah matematika: Cara siswa memperoleh jalan untuk berpikir kreatif dan sikap positif [Mathematics problem solving: The way of students to acquire creative thinking and positive attitudes]. Bandung, Indonesia: Alfabeta.

Polya, G. (1973). How to solve it (2 ed.). Princeton, NJ: Princeton University Press.

Polya, G. (1981). Mathematical discovery: On understanding, learning and teaching problem solving. New York, NY: John Wiley \& Sons, Inc.

Posamenteir, A. S., \& Krulik, S. (2009). Problem solving in mathematics grades 3-6, powerful strategies to deepen understanding. Thousand Oaks, CA: Corwin A SAGE Company. 
Tri Dyah Prastiti, $d k k$. - Pengembangan Lembar Kerja

Mahasiswa Berbasis High Orderthinking Skills pada

Matakuliah Matematika di Universitas Terbuka

Siswono, T. Y. (2008). Model pembelajaran matematika berbasis pengajuan dan pemecahan masalah untuk meningkatkan kemampuan berpikir kreatif. Surabaya, Indonesia: Unesa University Press.

Suwarma, D. M. (2009). Suatu alternatif pembelajaran: Kemampuan berpikir kritis matematika. Jakarta: Cakrawala Maha Karya.

Universitas Terbuka. (2016). Katalog FKIP program pendidikan guru SD dan PAUD Universitas Terbuka 2016. Jakarta: UT. 